\title{
Hairy polyp of the nasal vestibule
}

\author{
Oluyori Kutulola Adegun, ${ }^{1}$ Hala Kanona, ${ }^{2}$ Jonathan Joseph, ${ }^{2}$ Amrita Jay ${ }^{1}$
}

${ }^{1}$ Department of Cellular Pathology, University College London Hospitals NHS Foundation Trust, London, UK ${ }^{2}$ Royal National ENT and Eastman Dental Hospitals, University College London Hospitals NHS Foundation Trust, London, UK

\section{Correspondence to} Dr Oluyori Kutulola Adegun; o.k.adegun@qmul.ac.uk

Accepted 20 May 2021

\section{DESCRIPTION}

A male infant was born with a pendulous fleshy mass attached to the right nasal vestibule (figure 1A). The mass caused nasal deviation and interfered with feeding. Bilateral preauricular skin tags, bilateral clefts, a lip pit under the left nostril and dermoid on the limbus of the left eye were also seen on clinical examination. MRI of the head to investigate for intracranial extension revealed bilateral trigeminal nerve hypoplasia, as well as hypoplasia of the right internal auditory meatus with complete atresia of the right facial, cochlear and vestibular nerves. Surgical excision of the nasal mass was performed to alleviate feeding difficulty and for histopathological evaluation. Histology revealed a pedunculated polyp lined by epidermis (figure 1B), with the superficial stroma featuring numerous adnexal structures including hair follicles, sebaceous and eccrine glands and erector pili muscle (figure 1C). The central parts of stroma contained loose cellular fibrous tissue with spindle cells, many variably sized lymphatic spaces and fewer thick-walled blood vessels. Cartilaginous tissue was present near the pedicle (figure 1D). A histological diagnosis of hairy polyp arising from the nasal vestibule was reached. This site of presentation is unusual as most reported cases are within the oropharynx, nasopharynx and middle ear. ${ }^{1-3}$ In view of the other first and second branchial arch anomalies noted on clinical examination and on MRI, the features were considered

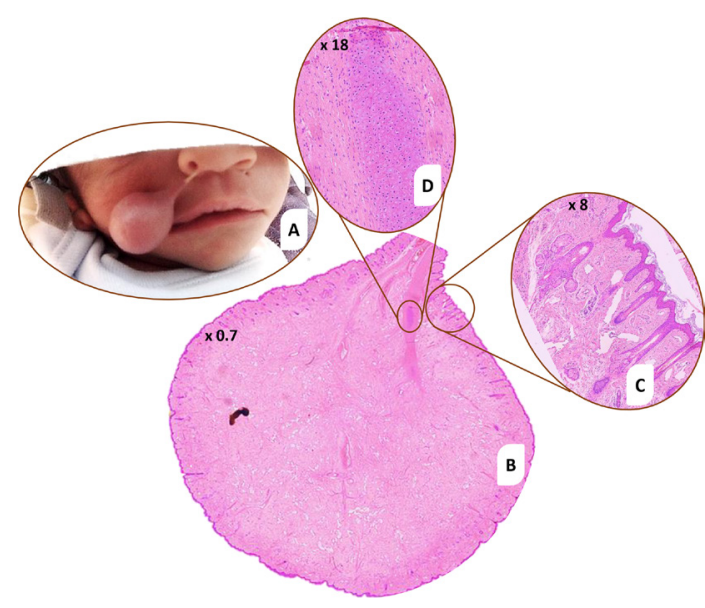

Figure 1 (A) Clinical image of smooth surfaced pendulous polypoid mass attached to the right nasal vestibule. (D) Histology images of pedunculated polyp lined by epidermis. (C) Overlying epidermis and adnexal structures including hair follicles, sebaceous and eccrine glands. (B) Cartilage near the pedicle. within the spectrum of Goldenhar syndrome (oculo-auriculo-vertebral spectrum). These findings further support the hypothesis that structures which develop from the first pharyngeal pouch or second branchial arch are possible sites for development of hairy polyps. ${ }^{4}$ In conclusion, hairy polyp is a developmental anomaly which can be isolated or occur in association with congenital malformations including first and second arch anomalies, facial hemihypertrophy, cleft palate, etc. Clinical suspicion of a congenital anomaly at this site should prompt imaging studies before management to ensure absence of intracranial extension.

\section{Learning points}

- Hairy polyp, also known as a teratoid polyp or dermoid polyp, is a benign polypoid lesion of developmental origin, composed of ectoderm and mesoderm.

- Depending on the location of a hairy polyp, the differential diagnosis can include but is not limited to teratoma, encephalocele, craniopharyngioma, dermoid cyst, hamartoma, glioma, etc.

- Histological examination is crucial in distinguishing hairy polyp from other congenital anomalies including teratomas, hamartomas, dermoid cyst and choristoma.

Correction notice This article has been corrected since it has been published online. The figure legends and part labels has been update to match the description in the text.

Contributors OKA, HK, JJ and AJ were involved in the surgical management, histopathological evaluation and preparation of the case report manuscript.

Funding The authors have not declared a specific grant for this research from any funding agency in the public, commercial or not-for-profit sectors.

Competing interests None declared.

Patient consent for publication Parental/guardian consent obtained.

Provenance and peer review Not commissioned; externally peer reviewed.

\section{REFERENCES}

1 White LI, Shehata BM, Rajan R. Hairy polyp of the anterior nasal cavity. Otolaryngol Head Neck Surg 2013;149:961-2.

2 Cone BM, Taweevisit M, Shenoda S, et al. Pharyngeal hairy polyps: five new cases and review of the literature. Fetal Pediatr Pathol 2012:31:184-9.

3 Tariq MU, Din NU, Bashir MR. Hairy polyp, a clinicopathologic study of four cases. Head Neck Pathol 2013;7:232-5.

4 Simmonds JC, Jabbour J, Vaughn JA, et al. Hairy polyps: a new case presentation and a pathogenetic hypothesis. Laryngoscope 2019;129:2398-402. 
Images in...

Copyright 2021 BMJ Publishing Group. All rights reserved. For permission to reuse any of this content visit https://www.bmj.com/company/products-services/rights-and-licensing/permissions/

BMJ Case Report Fellows may re-use this article for personal use and teaching without any further permission.

Become a Fellow of BMJ Case Reports today and you can:

- Submit as many cases as you like

- Enjoy fast sympathetic peer review and rapid publication of accepted articles

Access all the published articles

Re-use any of the published material for personal use and teaching without further permission

Customer Service

If you have any further queries about your subscription, please contact our customer services team on +44 (0) 2071111105 or via email at support@bmj.com.

Visit casereports.bmj.com for more articles like this and to become a Fellow 